\title{
DIGITAL PRESERVATION OF ANCIENT MAYA CAVE ARCHITECTURE: RECENT FIELD EFFORTS IN QUINTANA ROO, MEXICO
}

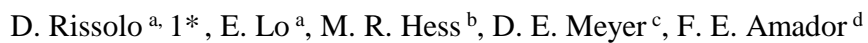 \\ ${ }^{a}$ Center of Interdisciplinary Science for Art, Architecture, and Archaeology (CISA3), University of California, San Diego, USA \\ - (drissolo, eklo)@ucsd.edu \\ b Dept. of Structural Engineering, University of California, San Diego, USA - mrhess@ ucsd.edu \\ ${ }^{c}$ Dept. of Computer Science and Engineering, University of California, San Diego, USA - demeyer@ucsd.edu \\ ${ }^{\mathrm{d}}$ Fundacion OLAS, Washington, DC, USA - fundacionolas@gmail.com
}

\section{Commission VI, WG VI/4}

KEY WORDS: Maya, Caves, Architecture, Mexico, Digital Preservation

\begin{abstract}
:
The presence of ancient Maya shrines in caves serves as unequivocal evidence for the ritual appropriation of these subterranean spaces and their significance with respect to Maya religious practice. Detailed study of the miniature masonry temples and altar features in the caves of Quintana Roo, Mexico reveals a strong stylistic and likely functional correspondence between these structures and their terrestrial counterparts at Postclassic sites. The Proyecto Arquitectura Subterranea de Quintana Roo (coordinated by the Center of Interdisciplinary Science for Art, Architecture, and Archaeology, or CISA3, at the University of California, San Diego and in collaboration with the Instituto Nacional de Antropologia e Historia in Mexico) is conducting a survey and program of digital documentation of both the pristine and impacted cave shrines of the region. Once an area is developed and populated, and access is opened to caves containing ancient architectural features, they are soon vandalized - often resulting in the complete obliteration of these rare miniature buildings and their diagnostic architectural elements. This emergent situation necessitates the use of rapid reality-capture tools; however, the physical challenges of working in caves requires researchers of adapt increasingly common architectural documentation methodologies to more adverse field conditions.
\end{abstract}

\section{INTRODUCTION}

Miniature versions of Postclassic Maya temples are commonly referred to as shrines, and the siting of these shrines inside caves was a tradition unique to the central east coast of the Yucatan Peninsula (Figure 1). For the ancient Maya, caves were an integral part of the sacred landscape, and were associated with the concepts of emergence and fertility. The Chacs, or rain gods, dwelled within watery caves and cenotes, and the Maya appealed to them though rites and rituals.

The presence of ancient Maya shrines in caves serves as unequivocal evidence for the ritual appropriation of these subterranean spaces and their significance with respect to Maya religious practice. Detailed study of the miniature masonry temples and altar features in the caves of Quintana Roo, Mexico reveals a strong stylistic and likely functional correspondence between these structures and their terrestrial counterparts at Postclassic sites such as Xamanha, Xcaret, Xelha, Tancah, and Tulum.

The smaller enigmatic temples of these coastal sites are often characterized by out-of-plumb, thickly stuccoed and painted walls supporting a roughly corbelled or beam-and-mortar roof, which enclose a single room typically containing a masonry altar or bench. Most readily identifiable are the mouldings that crown the temple buildings as well as the inset panels above temple doorways.
Unfortunately, these cave shrine sites reside within one of the most rapidly expanding tourism zones in North America, placing innumerable archaeological structures at risk. The focus of our fieldwork efforts has been on the rapid documentation and digital preservation of cave architecture in response to threats to Mexico's subterranean cultural heritage, and potential for these data to be applied to comparative analyses of surface and subsurface ceremonial architecture.

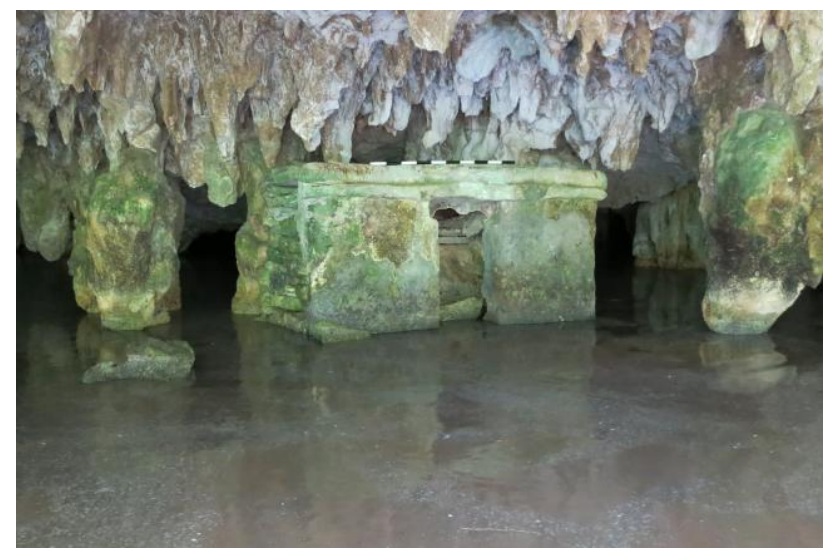

Figure 1. Well preserved shrine in a partially inundated cave known as "Aluxes" (photo by D. Rissolo). 


\section{PAST STUDIES}

Despite the region's enigmatic cave shrine tradition, surprisingly little has been done in terms of detailed investigations of cave sites within and around Xcaret and Xamanha. Andrews and Andrews (1975) recorded and described one cave altar and four cave shrines in the Punta Piedra area between the Xcaret site-center and Xamanha (see also Rissolo 2003:31-34 for a discussion). Leira and Terrones (1986) recorded an additional shine in this area, in a cave known as Aktun $\mathrm{Na}$ Kan. The cave survey of the CALICA property conducted by Martos López (2002:212-214) led to a discovery of a shrine in Cueva de Satachannah and an altar in Cueva de La Rosita.

One of the best preserved Maya caves shrines yet reported is located in a cave called Ocho Balas (also known as Oratorio) and is described in some detail by Rissolo et al. (2016). A related category of masonry features includes more open structures or platforms which served as altars. These are quite common in the caves of the central east coast region of Quintana Roo and have been documented and discussed by Rissolo (2004) and Martos Lopez (2010). Interestingly, these altars, and the miniature "thrones" which rest upon them, closely resemble such features found in temples and shrines at surface sites like Xamanha and Xel Ha.

\section{RECENT FIELD EFFORTS}

\subsection{Technical Challenges}

The project draws from a range of imaging capabilities including terrestrial laser scanning (TLS), structure-frommotion (SfM) photogrammetry, and stereo spherical giga-pixel photography. The latter produces navigable 3D point-of-view panoramas than can capture and allow for seamless and uninterrupted visual movement within and between light and dark areas, entrances, speleothems, and other subterranean features. These images complement the trusted geometry of the TLS point clouds and the photorealistic textured meshes produced via SfM.

The primary limitations, with respect to field operations, are lack of natural light and extraordinarily high humidity, as well as the difficulty of packing ample power and gear into the forest and across rugged terrain. SfM photogrammety has emerged as a preferred technique, although appropriate cameras, lenses, and portable lights are essential.

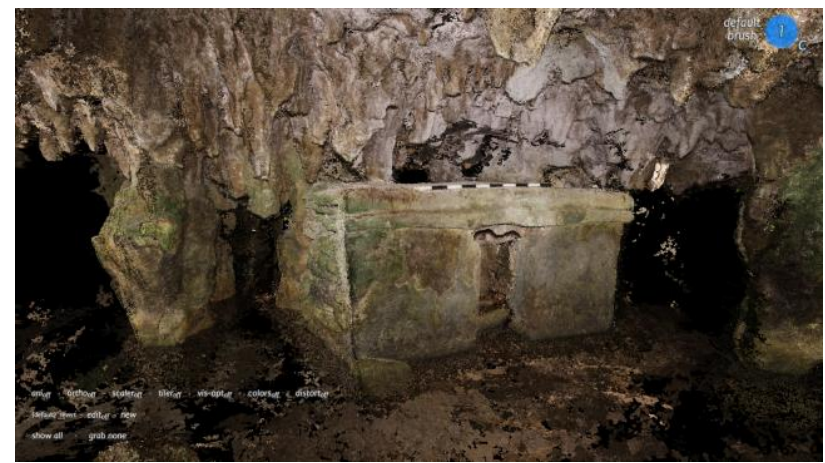

Figure 2. Point cloud (via SfM photogrammetry) of the shrine in the cave known as "Aluxes."
The shrine in "Aluxes" is relatively well known to local cave explorers and archaeologists. The structure is in a remarkable state of preservation and resembles the shine in Ocho Balas (Rissolo et al. 2016). The area around the shrine has become inundated since the miniature building was constructed during the Postclassic period (obscuring the low platform upon which the shine was constructed). Reflection of light off the water's surface proved somewhat problematic with respect to photogrammetry (Figure 2). Moreover, the close proximity of the shrine's back wall to large stalactites made portions of the structure difficult to illuminate.

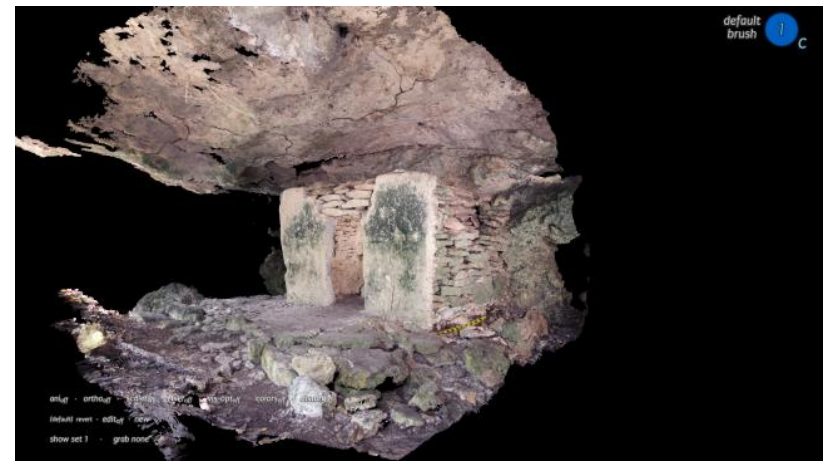

Figure 3. Point cloud (via SfM photogrammetry) of cave shrine XH-1 (note un-plastered sidewalls).

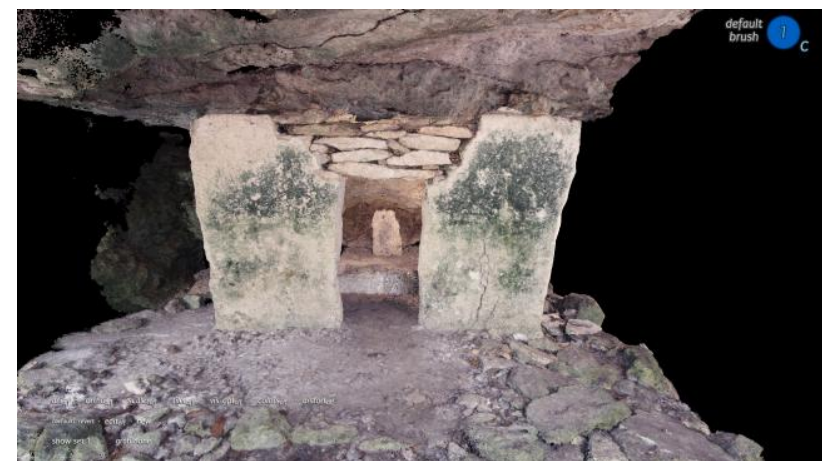

Figure 4. Point cloud (via SfM photogrammetry) of cave shrine $\mathrm{XH}-1$, frontal view (note intact altar and "throne").

The cave shrine $\mathrm{XH}-1$ is located above the edge of a cenote in an open rock shelter environment (Figures 3 and 4). There is abundant natural daylight, which allowed for less artificial lighting to be used in the imaging of the shrine. However, the shadows produced by dappled sunlight are not optimal for SfM photogrammety. In such instances, fill lighting (onboard the camera rig) is used. The Shine XH-1 incorporates the back wall of the cave and the low cave ceiling into the structure itself. As is common among many cave shrines and altars in Quintana Roo, there is evidence of more recent reconstruction and reuse.

Cave shrines $\mathrm{X}-1$ and $\mathrm{X}-2$ are located in relatively close proximity to one another. These shrines are in twilight or near total darkness, which allows for better control of lighting. Shrine X-1 (Figures 5 and 6) is located in a low room and proved challenging for manipulating the camera and lighting rig. Unique to $\mathrm{X}-1$ is the positioning of the doorway of the structure directly below a karst window, which illuminates the interior space of the shrine. The side walls meet the roof of the chamber, concentrating the daylight through the doorway and onto the altar within the shrine. 


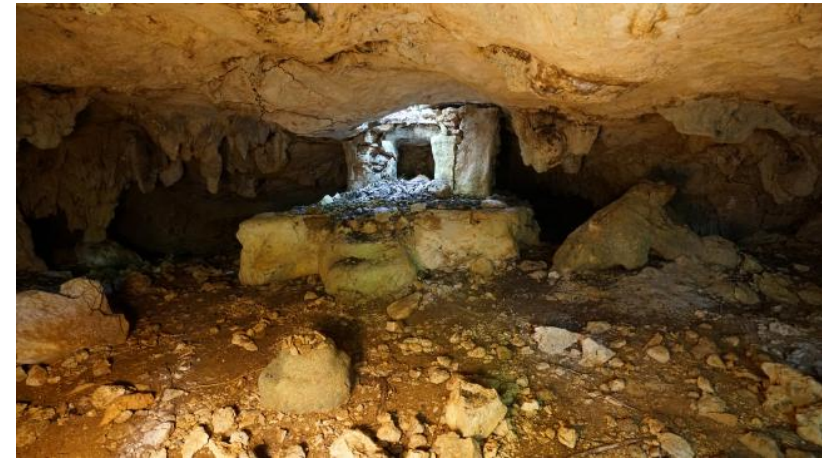

Figure 5. Shrine $\mathrm{X}-1$. Note natural light from karst window in front of doorway. (Photo by D. Rissolo).

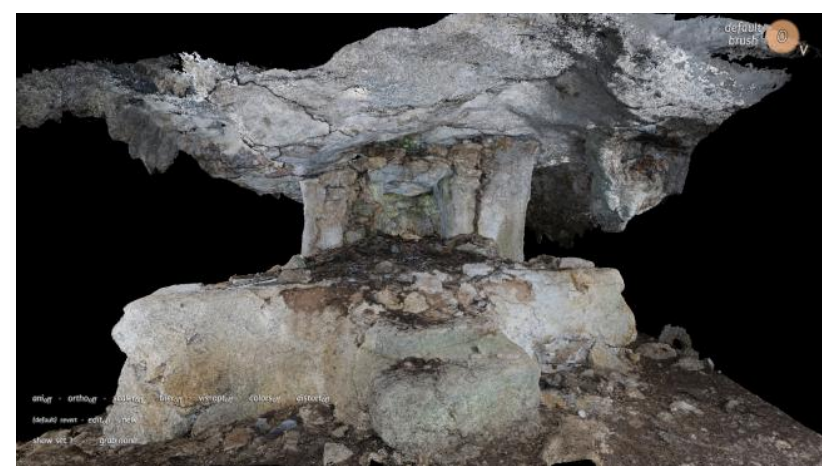

Figure 6. Point cloud (via SfM photogrammetry) of Shrine X-1.

The cave shrine X-2 (figure 7) is similar in morphology to XH1 , making use of a low cave ceiling and a cluster of speleothems to create a more enclosed environment. This shrine has been significantly damaged as a result of looting. The entire back wall and the back of the altar were ripped out. Interestingly, this damage to the structure exposed evidence that the enclosed shrine was at one time an unenclosed altar platform (with the walls and ceiling added later). Again, such modifications and reuse of these structures by the Maya over time was common. What these practices might reveal about Maya ceremonial cave use during the Postclassic would be a potential topic of study.

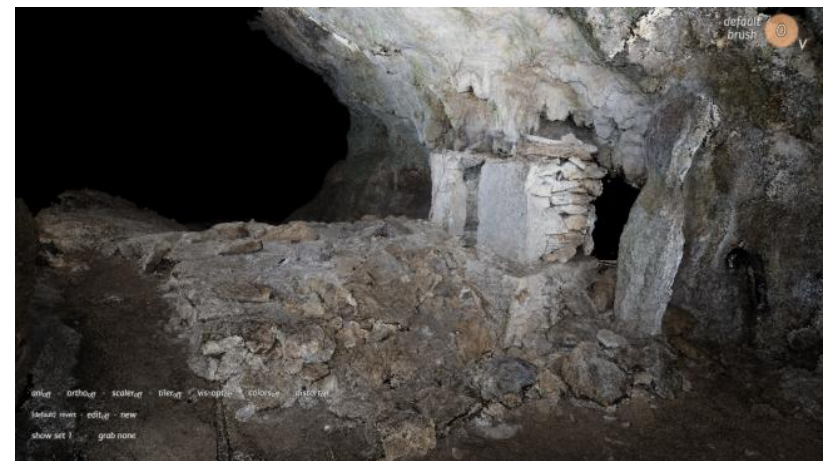

Figure 7. Point cloud (via SfM photogrammetry) of cave shrine

$\mathrm{X}-2$. Note the un-plastered sidewalls (similar to XH-1).

\subsection{Social, Cultural, and Political Challenges}

Perhaps the greatest single challenge to digitally preserving these rapidly disappearing cave shrines is access. Complex and ever-changing land tenure realities - involving a range of actors, from indigenous communities to international real estate investors - often determine whether or not Maya cave shrines can be recorded in advance of impending vandalism or looting.
Xcaret and Xamanha were the ports of embarkation for one of the most important pilgrimage destinations and centers of commerce during the lowland Maya Postclassic: Cozumel. Following the hundreds of years of isolation and relative obscurity that befell the region after its decline during the $15^{\text {th }}$ and $16^{\text {th }}$ centuries, Xcaret and Xamanha have recently reemerged to once again assume what can be argued as functionally identical roles. The city of Playa del Carmen, which sits atop ancient Xamanha, is one of the fastest growing urban zones in Mexico. The site of Xcaret - including the entire surrounding landscape and shoreline - has been completely transformed to accommodate a successful theme park. To further complicate matters for the archaeologists and cultural heritage practitioners, this section of the Riviera Maya has witnessed a proliferation of all-inclusive mega-resorts along the coast and the creation of the massive CALICA limestone gravel quarry.

More traditional approaches to archaeological survey are often ineffective along the central east coast of Quintana Roo. Much time and effort are spent interacting with real estate developers, land surveyors, tourism entrepreneurs, and the like. Efforts to document vulnerable cave architecture in the region not only requires access to the few remaining parcels of undeveloped land, but we need to visit and re-evaluate those caves currently below or surrounded by luxury hotels, golf courses, shopping malls, and housing developments.

\section{CONCLUSIONS}

Longstanding federal legislation regarding cultural heritage protections in Mexico combined with active measures undertaken by the Instituto Nacional de Antropologia e Historia to safeguard at-risk sites has gone a long way towards mitigating impacts to cave sites in Quintana Roo. Nevertheless, the sheer scope and scale of landscape transformation in the region has proven to be a challenge. The difficulties inherent in digital documentation of cave sites - such as inundation, physical restrictions, heat, humidity, and darkness - combined with a myriad of ever-changing access issues, and the sense of urgency brought on by accelerated development, makes for an atypical digital heritage survey in the Maya area. Nevertheless, the Proyecto Arquitectura Subterranea de Quintana Roo is committed to rapid digitization, curation, and dissemination involving these once hidden heritage sites of Mexico.

\section{ACKNOWLEDGEMENTS}

Research was conducted under the auspices of the Instituto Nacional de Antropologia e Historia (INAH), and we wish to thank the staff of Centro INAH Quintana Roo, under the directorship of Adriana Velazquez Morlet. The project is supported by the Strauss Family Fund for Mesoamerican Studies, with initial fieldwork supported by the National Science Foundation (NSF), grant DGE-0966375, and the Kinsella Endowed Fund. We would like to thank the following individuals for their invaluable contribution to the project: Zoë Abrahams, Jorge Avila, Adrienne Bolli, James E. Brady, David Carillo, James Coke, Gabrielle Coulousi, Miguel Covarrubias, Fred Devos, Tiffany Fox, Jeffrey Glover, Aliya Hoff, Jennifer Hollis, Marcia Kirby, Falko Kuester, Crystal Liu, Christopher McFarland, Samuel Meacham, Henrik Nikander, Monica Olivares, Vid Petrovic, Bil Phillips, Tania Ramirez, Carmen Rojas, Peter Sprouse, Brian Strauss, and Otto von Bertrab. 


\section{REFERENCES}

Andrews IV, E.W. and Andrews, A.P., 1975. A Preliminary Study of the Ruins of Xcaret, Quintana Roo, Mexico: With Notes on Other Archaeological Remains on the Central East Coast of the Yucatán Peninsula. New Orleans: Tulane University, Middle American Research Institute, Publication 40 .

Leira Guillermo, L.J. and Terrones Gonzalez, E., 1986. Aktun $\mathrm{Na}$ Kan. Boletín de la Escuela de Ciencias Antropológicas de las Universidad de Yucatán 14(79):3-10.

Martos Lopez, L.A., 2002. Por las Tierras Mayas: Arqueología en la Área de CALICA, Quintana Roo, México. INAH, Mexico City.

Martos Lopez, L.A., 2010. Cuevas de la Region CentralOriental de la Peninsula de Yucatan: Un Analisis desde la Perspectiva Simbolica. Doctoral Disseration, Escuela Nacional de Antropologia e Historia, Mexico City.

Rissolo, D., 2003. Ancient Maya Cave Use in the Yalahau Region, Northern Quintana Roo, Mexico. Austin: Association for Mexican Cave Studies.

Rissolo, D., 2004. Maya Cave Shrines along the Central Coast of Quintana Roo. AMCS Activities Newsletter 27:57-59.

Rissolo, D., Hess, M.R., Hoff, A.R., Meyer, D., Amador, F.E., Velazquez Morelet, A., Petrovic, V., Kuester, F., 2016. Imaging and Visualizing Maya Cave Shrines in Northern Quintana Roo, Mexico. In Proceedings of the $8^{\text {th }}$ International Congress on Archaeology, Computer Graphics, Cultural Heritage, and Innovation, pp. 382-384. Editorial Universitat Politecnica de Valencia, Spain. 